\title{
THE STUDY OF HISTORICAL BACKGROUND OF MUMMIES OF EGYPTIAN PHARAOHS FOUND IN EGYPTIAN ARCHEOLOGY
}

\author{
Abdul Khaliq \\ Assistant Controller of Exams \\ Lasbela University of Agriculture, Water \&Marine Sciences \\ Uthal-Pakistan \\ ak.aleemik@gmail.com \\ Hafiz Salahudin \\ Assistant Professor \\ Lasbela University of Agriculture, Water \&Marine Sciences \\ Uthal-Pakistan \\ salahuddin@luawms.edu.pk \\ Shumaila Kamal Khan \\ Lecturer \\ Department of Sociology \\ Lasbela University of Agriculture, Water \& Marine Sciences \\ Uthal-Pakistan \\ shumaila_kamal88@yahoo.com
}

\begin{abstract}
The man tried his level best in different ways to save himself for long in human history. Mummification is one of the ways to save human body forever. This is really a miracle of ancient world. Having less means and no technology, man invented the idea of mummification and saved the body for long. Thousands of mummies were found in different parts of the world. Especially, the mummies of ancient Egypt are unique. The Egyptians utilized the best method and materials in the mummification of the bodies. Many famous pharaohs` mummies were discovered by experts in excavation. These mummies also contribute for exploring the Egyptian history. The mummy of Mereneptah was found from the archaeological site and Allah preserved his body and made it a sign for the later generations. He was the Pharaoh who went back Hazarat Moses (PBUH) and fallen in the sea. Egyptians used to make the mummies of the animals
\end{abstract}




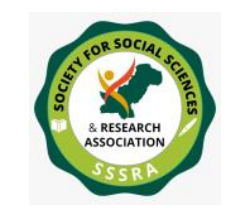

Pak. Journal of Int'L Affairs, Vol 4, Issue 4 (2021)

The Study of Historical Background of ...

which they consider their gods. Many mummies of animals were found in the ruins of the ancient Egypt.

Keywords: Mummy, Methodology of Mummification, Preservation of Mummies, Mummies of Animals, Manchester Museum

\section{Introduction}

In ancient times, human beings made mummies of human body and astonished human beings. Mummies have been discovered from different parts of the world. The history of ancient Egypt is incomplete without mentioning the mummies of Pharaohs of ancient Egypt. On the contrary, these mummies are the main source of the history of ancient Egypt, due to which the history of ancient Egypt is compiled. The most important material on Egyptian history was in the library in Alexandria. Which was destroyed in the attack of Alexander the Great. Archaeologists are still struggling to gather enough evidence before reaching the final conclusions about the location of the mummies. These mummies are housed in various museums around the world.

When the pharaohs of Egypt died, their bodies were embalmed in a special way so that they would be preserved for a long time. They believed that if they were resurrected, they would have all these facilities.

\section{Mummies`Literal Meaning}

Explaining the literal meaning of mummy, Maulvi Feroz-ud-Din wrote : "Mummy: The corpse should be preserved with spices - ".Children love to be called mothers." (Ferozuddin, 2010). Herodotus visited Egypt in 450 BC. At the time of his visit, he witnessed the mourning, the rituals, and the manner in which the corpse was mummified, quoting Herodotu, J-R-Rahay writes: "When an honorable man dies, the women of his house go out with chador on their chests and mud on their heads. Sometimes she puts mud on her face and walks around in the bazaar with her chest pierced. The women of their relationship also join them. And weep. Men also weep separately with their headscarves tied around their chests. When the mourning rituals are over, the corpses are taken to the spice planters. There is a group of people whose special profession is to spice up the corpses of men and save them forever" (Rai, 2014).

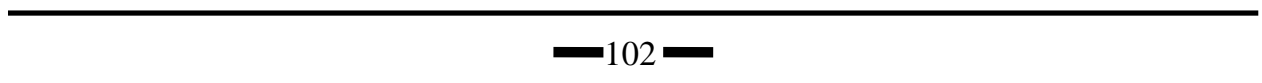




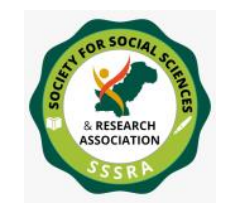

In ancient times people had no idea of the afterlife. They believed that once they died, they would be gone forever, so they made mummies with spices in a special way to preserve their bodies for a long time. This was done in many countries of the world. Explaining this, Yasir Jawad wrote: Mummy ... A term used to describe a human body preserved by the natural environment or by special methods of embalming. Mummies have been found in many parts of the world. Including Egypt, other parts of North Africa, the Middle East, South America, the Peruvian desert region, western China and second Nuba. However, only mummies made in Egypt between 3400 BC and 641 are considered real mummies (Jawad, 2009).

Egyptians particularly involved in the stripping of mummies and the opening ceremony of the mouth ritual. Experts have done great work on Egyptian mummies. Discovered many mummies. Especially discovered the mummies of the great pharaohs and kings. Their bodies were mummified in various ways .

\section{Methodology of Mummification}

In ancient Egypt, before the corpse was mummified, the body was operated on and all the intestines and other things were removed from its stomach. Then it was washed with a special drink. Explaining the whole process of making mummies, referring to the tourist Herodotus. J.R. Ra writes":The brain was extracted by inserting tongs in the nostrils of the dead with various special medicines. Then the intestines etc. were taken out by piercing the side with a stone knife. And the stomach was washed with palm wine. Then the fragrant things were poured on it. Hepar used to grind dead and bay leaves and similar fragrant things to close the cross wound in the stomach. The body was then immersed in soda for seventy days. Later it was taken out and washed, and sheets and bandages were wrapped around it. In which glue was applied. People who could not afford to spend more money. His corpse was made in such a way that without removing the intestines, cedar oil was injected into the mouth. The body was then thrown into the soda. It was taken out after a certain period. In the meanwhile, because of oil, the intestines used to melt and become water. The effect of the soda was to melt the meat. And only the structure was left. The heirs would take him and put him in a coffin and bury him ( Rai, 2014).

Making a mummy of the human body meant that the ancient Egyptians had to operate on the internal parts of the body, which gave them information about internal organs and surgery. Charlotte Booth writes: "The ancient Egyptians 


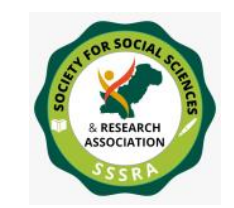

The Study of Historical Background of ...

had a remarkable understanding of the human body, mainly gained through their interpretations in the course of mummification. They perhaps didn't execute live internal surgery, but their highest anatomical accomplishment was the neardiscovery of transmission (Booth, 2011)

Wendy Christensen writes: "for thousands of years the Egyptian physician-priests had been mummifying human bodies. However, they looked at corpses as sacred, not scientific objects, they still had very little understanding about human anatomy. Their goal was to save the body, not to understand it (Christensen, 2009).

Wendy is saying in the above passage that Egyptian physicians were not scientists and their purpose was not to understand the body but to preserve it for a long time.

\section{Preservation of Mummies}

In ancient Egypt, serious arrangements were made for the protection of mummies. The Egyptians considered their protection a religious duty. Large tombs and pyramids were built for the mummies. Explaining the reason for keeping mummy in the Haram, Yasir Jawad writes :According to the ancient Egyptian belief, the ruler used to go to the next life through the pyramid in that mummy was kept (Jawad, 2009).

Ancient Egyptian tombs contain information about the lives of Egyptians from birth to death. Experts have turned a lot of information from these tombs in books. Charlotte Booth is wealthy, stating researchers have found a great deal of information on mummies and tombs. Based on this information, the links of history have been properly combined and given a direction. Charlotte Booth writes: "Most information about ancient Egypt comes from research and exploration of tombs and temples. Although these structures and the treasures they hold are truly fascinating, examining only tombs, mummies, and treasures gives a biased view of the Egyptians as a morbid nation that was obsessed with death" (Booth, 2011).

These mummies were buried in the pyramids with valuables or in separate tombs for them. Many mummies were destroyed by thieves because of their valuables. And this has been going on for a long time. Explaining the reason for stealing from pyramids and tombs, Allama Ibn Khaldun writes: "Egypt has been a 


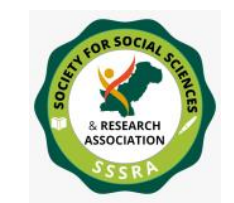

kingdom for thousands of years. And they had a constitution. That they used to bury all his property with the man in the manner of Umm Qadeem in the form of cash and sex. When the time of the Copts passed and the Persians came to Egypt, they dug up the graves of the Copts and extracted a lot of wealth and jewels from them. The Greeks, who became the masters of Egypt after the Parsis, did the same. And often digging graves brings wealth. And their graves have been excavated for thousands of years and gold and silver pillars are found in their graves ( Allahabadi, 2009)

But now Egyptian archeology is well monitored, and the mummies of some of these pharaohs have been preserved in the Cairo Museum, as well as in the London Museum. These mummies have been found with the hard work and dedication of archaeologists. And this work is still going on. Because of them, a lot of information has been gathered. When French scientist Dr. Maurice Bocaille examined Pharaoh's mummy, he was attracted to Islamic teachings and he himself learned Islam and became a Muslim inspired by Islamic teachings and wrote a book on Islam.

\section{The Mummy of Rameses}

Pharaoh Ramesses II is a great Pharaoh. This is Pharaoh. During the reign of Prophet Moses (peace be upon him) was born and who wanted to kill him as soon as he was born. But by the grace of Allah, Prophet Moses (peace be upon him) was brought up in the house of this Pharaoh. By the time he reached Madinah, this Pharaoh had died. Bob Brier, Hoyt Hobbs writes in his book "Daily life of the Ancient Egyptians" about the mummy of Pharaoh Ramesses II in his book:

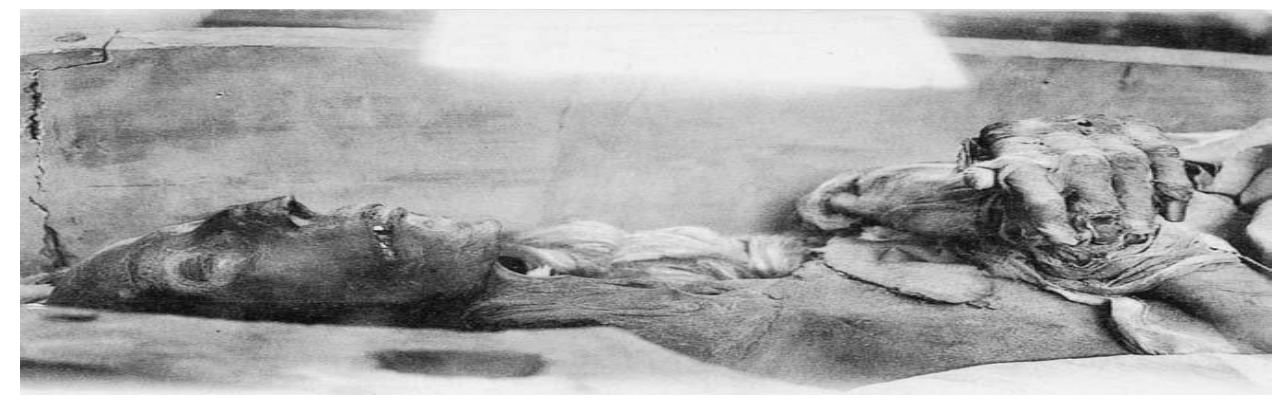

"The mummy of Rameses the Great shows how well a body can be preserved for over three thousand years ( Brier \& Hobbs,2008).

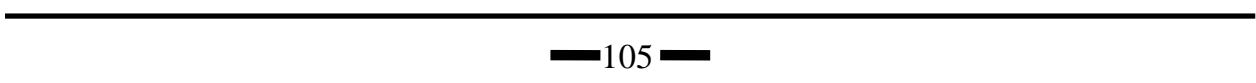


An excellent example of Egyptian mummy making is that despite the passage of time, their mummies are still intact. However, the human body is very fragile and quickly rots.

\section{Mummy of Merneptah}

After the death of Ramesses II, his son Marnaphtah became Pharaoh. It was contested on the return of Prophet Moses (peace be upon him) to Madinah. At the time of Maranfatah's exodus, following the Prophet Moses (peace be upon him) and the children of Israel, they crossed the sea and later their bodies were found by the sea which was made mummy and saved forever. In the last century, his mummy fell into the hands of archaeologists, who are described in detail in the following chapters.

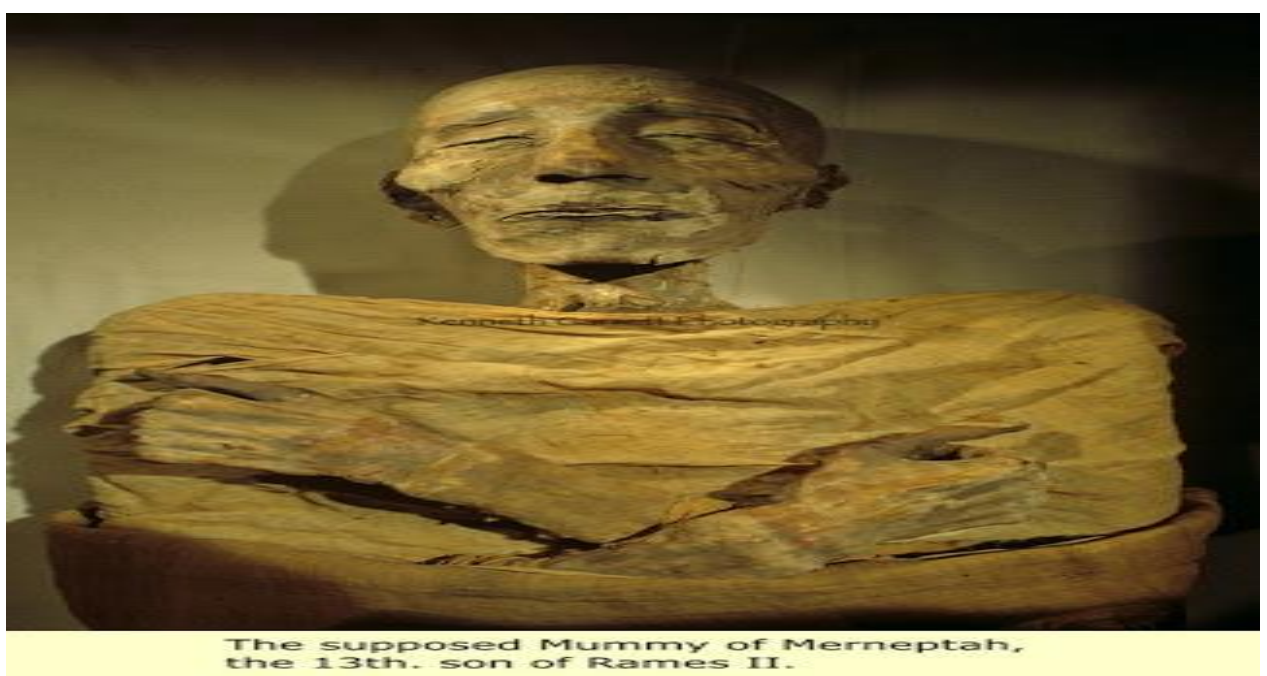

(https://www.google.com/search?q=mummy+of+tutankhamun\&sxsrf)

This is the mummy of this Pharaoh. Which was lost in the sea at the time of exodus. According to Quran, it will be a sign for the later generations. When his body came out of the sea, then the children of Israel also observed it and then his mummy was made and saved, nowadays the whole world is watching him and learning a lesson. The Qur'an says:

(13) 


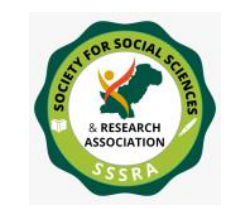

The Study of Historical Background of ...

So today We will save you from your body (of annihilation) so that you may be a sign for the later ones, and surely many people are heedless of Our signs.

\section{Tutankhamun's Mummy}

Tutankhamun was a great pharaoh in the history of Egypt. He became Pharaoh after Akhenaten. He abolished Akhnaton's reforms of monotheism in all of ancient Egypt and brought Egypt back to the old stage. Restored temples and other deities that had been banned by Akhenaten. The tomb of Tutankhamun was discovered in the last century. This discovery was a great achievement for the experts. The news was well received. Charlotte Booth wrote: "Tutankhamun's tomb is one of the most famous and monumental finds in the history of Egyptology, because it is the only undisturbed royal tomb found in Egypt. All the other royal tombs were robbed in antiquity, and indeed so was Tutankhamun's. Luckily, these burglaries were small, and the majority of Tutankhamun's goods were found intact..... Luckily for Carter this final season was a cracker. On 4 November 1922 his team uncovered the first stone step of Tutankhamun's tomb. The next day they cleared the steps to reveal the door, complete with ancient seals showing the tomb was intact. The first doorway was opened on 23 November 1922, and the second doorway within the tomb on 26 November. At the opening of this door, Carter and Carnarvon saw for the first time the wonderful objects hidden for three millennia. These include solid gold coffins, gilded shrines, scores of pieces of golden jewelry, and the famous solid gold death mask...... 28 October 1925 the team finally opened the coffin and gazed at the face of the king who lived and died so long ago ( Booth, 2011).

Of course, it was a great achievement for the experts that they discovered the first tomb intact. It was breaking news all over the world at that time. And especially in Europe, their success was praised and greatly appreciated. This is a picture of Tutankhamun's mummy taken from a website. 


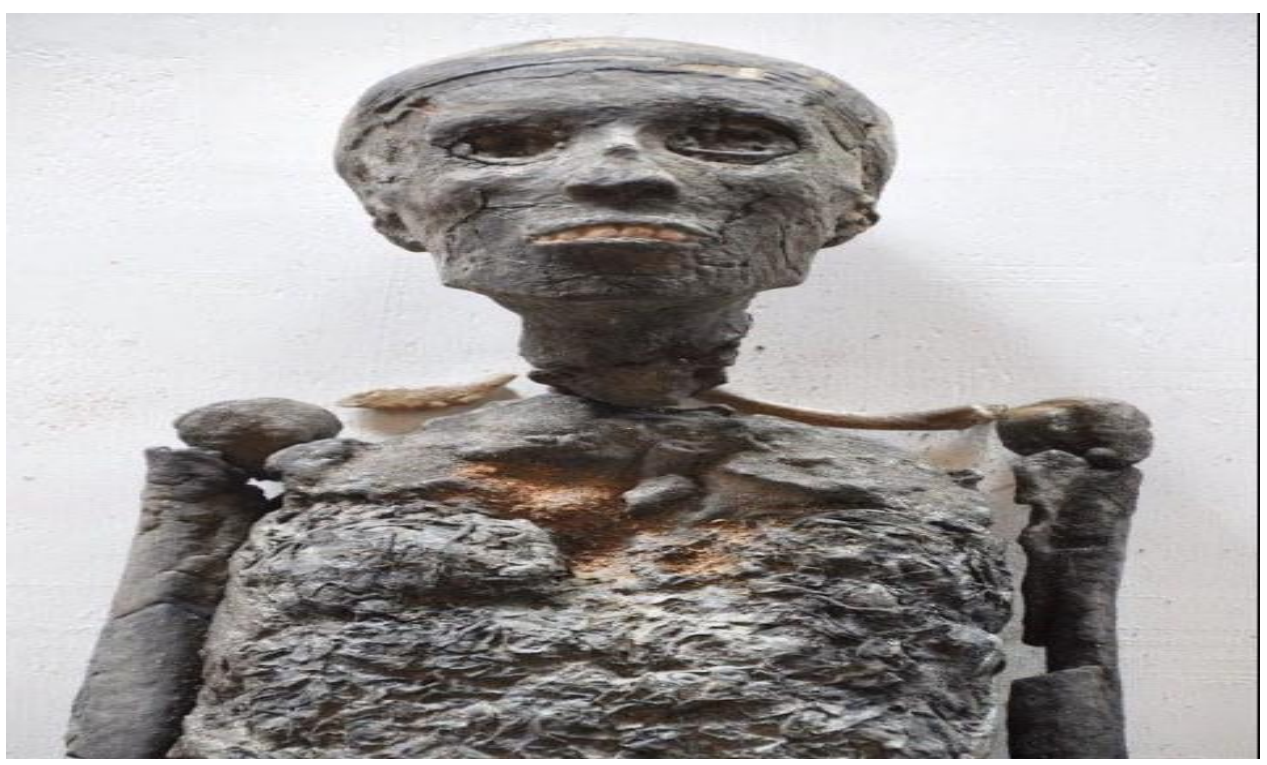

\section{Mummies of Sacred Animals}

The Egyptians worshiped many animals as deities, so when they died, they made mummies and buried them. Experts have found thousands of such animals. Referring to the crocodile mummy, Geraldine Pinch writes: "Crocodiles were kept as sacred animals in some temples and mummified after death (Pinch, 2002)

Crocodile mummies were made in ancient Egypt. Geraldine Pinch gives a picture of some of these crocodile mummies in her book (Pinch, 2002).

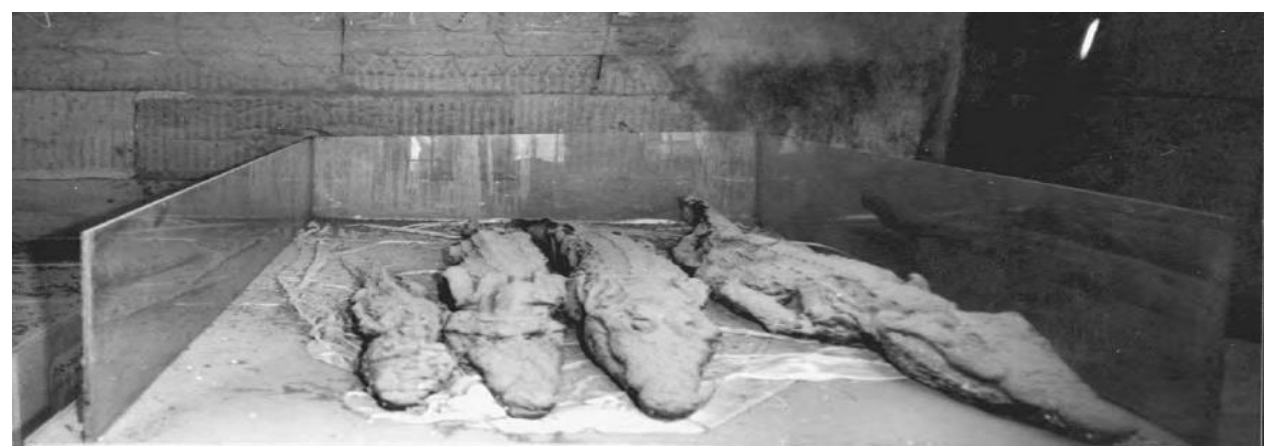

Mummified sacred crocodiles stored in the temple of Sobek and Horus at Kom Ombo. ${ }^{i}$ 


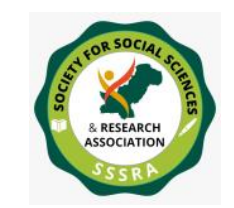

Different animals were considered gods. When they died, their mummies were made and buried, and there was a special graveyard for them. Herodotus writes :The dead cats have been taken to the town of Bo Bastis where they are embalmed and buried in a special sacred cemetery. The dogs are also buried in their respective cities and cemeteries. The same is true of the Pharaoh. On the other hand, the burial mounds of lizards and mice are carried to every mopolus. Only a few wolves from rare bears and foxes in Egypt are buried there ( Jawad 2005).

During excavations, experts found mummies of various animals. They were embalmed and saved by the Egyptians. Because they considered these animals as their gods. They treated their mummies with respect while maintaining their sanctity.

\section{Graveyard Mummies}

Pharaoh's mummies were kept in tombs and pyramids with royal burial. In addition to necessities of life, their servants and maids were also killed and buried with them. So that when they are resurrected, they will have them with them. Explaining this, Kathryn A.Bard \& Steven Blake write: All of the 1st Dynasty tombs at Abydos have subsidiary burials in rows around the royal burials, and this is the only time in ancient Egypt when humans were sacrificed for royal burials. Perhaps officials, priests, retainers and women from the royal household were sacrificed to serve their king in the afterlife. The tomb of Djer has the most subsidiary burials -338 , but the later royal burials have fewer. In later times, small servant statues may have become more acceptable substitutes (Kathryn \& Shubert 2005).

He uncovered a very interesting fact that his servants were buried along with Pharaoh. Some historians have written that his servants were buried alive. They were killed with tools and buried with the king according to this belief. That when the king wakes up after death, his servants should also be present. And because of this belief, their bodies were embalmed or mummified so that if they were resurrected, their bodies would also be fine.

Besides, Mr. Akhlaq Ahmad Qadri has written a very bitter truth. Which is summarized with reference to them. In the seventeenth and eighteenth centuries, when medicine was developed in Europe, he came up with the idea that chewing a morsel of old mummy meat would cure all kinds of diseases. In addition, if there 


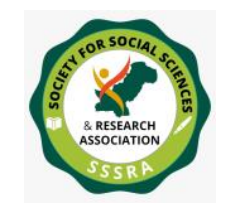

is any kind of wound, if the macro flesh of the mummy is turned on the wound, it will also heal. That is, it was declared the best antibiotic. As a result, ancient Egyptian mummies began to be sold in European stores. Thus, many mummies of ancient Egypt were lost. At the same time, men were exhumed from Christian cemeteries and their mummies were made. Which led to more diseases. In this way, the urge to treat mummies cooled down. And the remaining mummies of ancient Egypt escaped the cannibals of Europe (Qadri,2016).

\section{Manchester Museum}

The Manchester Museum in the United Kingdom houses many mummies from around the world. At first, the museum was not very popular. But when an Egyptian mummy was first scientifically examined in this museum. So, this museum became very popular through the media. Explaining the reputation of the museum and its importance, A.R. David writes: In 1975, the Manchester Museum became widely known through the Press and the media, when one of the Egyptian mummies in the collection was unwrapped and subjected to intensive investigation by a team of Egyptologists and medical and scientific experts from Manchester and elsewhere. This was the first time since 1908 that an Egyptian mummy had been scientifically dissected in Britain... The current project which was inaugurated in 1973 sought to use a wide range of the most recent medical and scientific techniques to examine all the human and animal mummies in the Manchester collection (David, 1996).

Mummies from around the world are being extensively investigated at the Manchester Museum. And a mummy data bank has been created by collecting all kinds of information about them. Explaining that A.R. David writes: "An International Mummy Data Bank, using the University Computer, has been established at the Museum. This holds information on mummies in collections around the world. Eventually, it is hoped that it may be possible to determine patterns of disease and diet in mummies from different periods and sociological groups (David, 1996)

It is very difficult to investigate mummies and gather information about them. But experts are making new discoveries with great interest in this work. And the facts about the diseases of mummies are being brought before the world. 


\section{Conclusion}

Mummy making was a very strange art in the ancient history of the world. Man has planned for a long time to preserve the rotting skin of the human body in times of misery and he succeeded in this. The discovery of these mummies proves that man was very large in ancient times. Mummies are one of the strangest assets of ancient Egypt. Research on ancient mummies is certainly a great achievement. On the basis of which history is being considered scientifically. It is a unique way for experts to study history in this way. Today's modern generation is being told about the very ancient times. What the people of the ancient times were like. As a result of these investigations, strange information about ancient times is being collected on daily basis. 


\section{References}

Allahabadi, (2009), History of Ibn Khaldun, Darul Ashaat, Urdu Bazaar MA Jinnah Road Karachi Pakistan, Volume I, Part II, Page 378

Booth,( 2011), The Ancient Egyptians for Dummies, John Wiley \& Sons, Ltd, The Atrium Southern Gate, Chichester, West Sussex, PO19 8SQ, England, Page No. 310, 29, 292

Brier, B., \& Hobbs, H.,(2008). Daily life of The Ancient Egyptians, London, 2nd edition, Greenwood Press Westport, Connecticut 56 (https://www.google.com/search?q=mummy+of+merneptah\&biw, 5.01pm, 15th August 2020)

Christensen, Empire of Ancient Egypt, http://www.chelseahouse.com, Page No. 69

David, A.R, (1996). The Pyramid Builders of Ancient Egypt, New York, Routledge 29 West 35th Street, NY 10001, USA, 1996, Page No. Page No. 08

Ferozuddin, (2010), Lahore, Feroz Sons (Private) Limited, 2010, 1287- 1288

Jawad (2009), Scientific Encyclopedia, Lahore, Al-Faisal Publishers and Traders Books Ghazni Street Urdu Bazaar, Vol. II, 1974 - 2010

Kathryn A. \& S Shubert, (2005), Encyclopedia of the Archaeology of Ancient Egypt, Taylor \& Francis e-Library, $34-35$ https://www.google.com/search?q=mummy+of+tutankhamun\&sxsrf

Pinch, (2002), A Hand Book of Egyptians Mythology, Santa Barbara, California • Denver, Colorado Oxford, England, Page No. 127,126

Jawad, (2005), The World's Oldest History, Lahore, Writings Publishers, 24. Mozang Road. Lahore, .156 -157

Qadri, (2016), History and Mystery of Pyramid, Lahore, Book Fort, Research \& Publications House No. 9, Street 32, Ghani Mohalla, Sant Nagar, Lahore, $.53-54$ 
Rai.J.R, (2014), Ancient Egypt, Lahore, Book Fort and Publications Ghani Mohalla Sant Nagar, p. 104, 105 